This is a pre-print version of an article accepted for publication in New Review of Film and Television Studies (Volume 14, Issue 3, 2016) following peer-review. The definitive publisher authenticated version will be available from: http://www.tandfonline.com/loi/rfts20\#.VzBqBqupp9s

\title{
From crime lab to mind palace: post-CSI forensics in Sherlock
}

\section{SOFIA BULL}

\begin{abstract}
This article examines the complex relationship between Sherlock (BBC, 2010-) and the forensic crime drama genre category. Tracing the televisual genre linkages that Sherlock articulates to previous programmes such as CSI: Crime Scene Investigation (CBS, 2000-15), Bones (Fox, 2005-), and Numb3rs (CBS, 2005-10), it specifically studies the show's need to distinguish itself within a television landscape oversaturated with forensic scientists. Discussing Sherlock's construction of the deductive method of investigation and genre subversive portrayal of the figure of the modern forensic expert, as well as its figuration of the consulting detective as an establishment watchdog, I conclude that this is a 'post-CSI' crime drama that stages a nostalgic resurrection of a pre-forensics cerebral gentleman detective.
\end{abstract}

\section{Keywords: Sherlock, Television, Genre, Forensics, Crime Drama, CSI}

The forensic crime genre was first established as a television drama category in the 1960s and 70s, when programmes such as Diagnosis: Unknown (CBS, 1960), Thorndyke (BBC, 1964), The Expert (BBC, 1968-76) and Quincy M.E. (NBC, 1976-83) celebrated the scientific crime investigator as a hero suitable for the technocratic revolution. While largely absent from television during the $1980 \mathrm{~s}$, police surgeons, medical examiners and forensic scientists then returned to centre stage during the mid-1990s. To begin with, this development was most noticeable in the UK where ITV and BBC featured a succession of forensic crime dramas, including McCallum (ITV, 1995-8), Dangerfield (BBC, 1995-9), Bliss (ITV, 1995, 1997), Silent Witness (BBC, 1996-) and Waking the Dead (BBC, 2000-11). On the other side of the Atlantic this shift was somewhat slower and 1990s programmes such as Diagnosis Murder (ABC, 1993-2001) and DaVinci Inquest (CBC, 1998-2005) were subsequently overshadowed by the arrival of CSI: Crime Scene Investigation (CBS, 2000-15, henceforth abbreviated ' $C S I$ '). The immense global success of $C S I$ played a crucial role in establishing the forensic crime drama as one of the pivotal television genres of the 2000s. CSI was followed by a wave of American shows featuring different types of forensic experts, such as Crossing Jordan (NBC, 2001-7), Without a Trace (CBS, 2002-9), Cold Case (CBS, 200310), NCIS (CBS, 2003-) Bones (Fox, 2005-), and Numb3rs (CBS, 2005-10), as well as the three spin-offs CSI: Miami (CBS, 2002-12), CSI: NY (CBS, 2004-13) and CSI: Cyber (CBS, 2015-). Most of these programmes have achieved wide global distribution and helped establish a transnational set of expectations tied to the forensic crime drama category.

In the early 2000s forensic crime dramas were still considered innovative, but they have since been firmly established as the mainstream. Recent years have witnessed increasing signs of oversaturation and there has been a general decline in forensic focused shows. Television workers and reviewers alike have begun to classify critically successful crime dramas as different from the forensic crime dramas, usually with reference to the recently cancelled CSI as a representative for the entire genre. Actress Elisabeth Moss, for example, assured viewers that Top of the Lake (Sundance Channel, 2013) would not be a 'CSI: New Zealand' (Lampert 2013; Rorke 2013) and Nic Pissolatto, the creator of True Detective (HBO, 2014), asserted that he "never [had the] ambition to make 'CSI: Louisiana'" (Blake 2014). Another program that has been discussed within this growing post-CSI discourse is Sherlock (BBC, 2010-), 
which features revamped incarnations of Arthur Conan Doyle's characters Sherlock Holmes and Dr John Watson. Sherlock has a particularly interesting and contradictory relationship to the forensic crime drama category. It clearly follows in the footsteps of shows such as CSI or Bones, but its creators Steven Moffat and Mark Gatiss have also repeatedly emphasised that it is not 'CSI: Baker Street' (Gilbert 2011).

A number of journalistic and academic studies have already discussed the figure of Sherlock Holmes as an important source of inspiration for the latest wave of forensic crime dramas (Thomas 1999, 4-5; Harrington 2007; Gere 2007, 129; Steenberg 2013, 23-49; Kompare 2010, 59; Williams 2011; Taylor 2012a; La Paz 2012). There are also numerous academic articles fruitfully comparing Sherlock to Conan Doyle's 'original' stories and other adaptations (Hills 2012; Scott-Zechlin 2012; Harrington 2012; Kustriz and Kohnen 2012; Basu 2012; Evans 2012; Steward 2012; Bochman 2012). There is, however, still a need for more in-depth discussions of Sherlock's complex relationship to the forensic crime genre category and of the programme's distinctly televisual form and context. While I will not discuss other Holmesian TV adaptations, my perspective has some similarities with Tom Steward's (2012) previous effort to trace the television contexts and histories of Sherlock, which has demonstrated that considerations of the programme's media specificity could produce fruitful insights that might be overlooked by cross-media adaptation studies. The article aims to contribute to the wider study of the complex ebbs and flows of television genre and I will therefore trace both linkages and ruptures between Sherlock and some of the forensics focused crime dramas that preceded it. My approach considers television genres as 'cultural categories' (Mittell 2004), which means that I discuss textual, contextual and paratextual aspects, as well as wider discursive expectations and assumptions linked to the genre category beyond the programmes themselves.

Using textual analysis, I will explore how different stylistic and ideological elements of Sherlock function through complex generic linkages. I will begin by discussing the programme's depiction of Holmes as a modern-day technology savvy investigator, arguing that it poses something of a problem in the current post-CSI context. Holmes, who was once hailed as the very first 'scientific detective', risks losing his exceptional status when transferred to a present-day setting where forensic science has become mainstream. I examine how the programme attempts to deal with this issue, primarily its construction of Holmes' deductive approach as a 'cerebral' method that marks him as different from the generic fictional forensic scientist on contemporary television. I also investigate Sherlock's derogative portrayal of the figure of the modern forensic scientist, showing that it subverts many of the conventions associated with the forensic crime drama and calls upon recent critical discourses surrounding the genre category in order to further assert its hero's exceptionality. I end my enquiry by comparing Sherlock's articulation of anxieties about state-funded science and biopower in 'The Hounds of Baskerville' (S02E02) with CSI's tendency to deflect such bioethical worries onto a reoccurring type of criminal type: scientists and medical doctors that commit crimes linked to their habit of practicing outside any official institution; a discussion that further illustrates how a combination of genre linkages and ruptures characterises the relationship between these two texts.

\section{Solving the 'Problem' of a Present-Day Sherlock Holmes}


As discussed in detail by many previous scholarly texts on Sherlock, one of the programme's main distinguishing features is its transferal of the classic characters from Victorian-era London to a present-day version of the city (Hills 2012; Scott-Zechlin 2012; Kustritz and Kohnen 2012; Basu 2012; Coppa 2012; Taylor 2012b; Bochman 2012). This premise is stressed by its almost obsessive narrative and visual focus on digital technology: Holmes' preferred method of communication is text messages and he repeatedly searches the Internet for information; Watson blogs about their adventures; Mycroft Holmes tracks his brother via London's extensive network of surveillance cameras; Irene Adler collects blackmail material on her camera phone; and Moriarty threatens to sell a computer code that can allegedly bypass all security systems. Digital technology is also evoked by the programme's visual style, which is riddled with graphic elements that allows text messages, e-mails and database searches to be displayed in superimposition onto the live-action playing out on the television screen.

As Tom Steward has pointed out, this visual tendency clearly echoes the foregrounding of 'new technologies intra-diegetically and in the production process' that has characterised most of the forensic crime dramas of the last two decades (Steward 2012, 144). In general, Sherlock's use of digital special effects, fast-paced editing techniques, montage sequences, and dynamic camera movements adheres to the wider and more long-running stylistic sensibility that John T. Caldwell has called 'televisuality': a tendency in contemporary television to 'flaunt and display style' as a response to the increased competition that network shows have faced from cable and other distribution channels since the 1980s (Caldwell 1995, 5). However, Sherlock's innovative visualizations of technology specifically follow in the footsteps of programmes such as CSI, Bones and Numb3rs, which characteristically established an analogy between their cutting-edge televisual style and the forensic technologies they portrayed (Lury 2005, 54). CSI used a snap zoom effect to illustrate the forensic scientists' ability to analyse traces with the latest DNA technology; Bones featured a 3D holographic table that visualised the forensic anthropologists' aptitude for examining human remains; and Numb3rs used superimposed graphics to illustrate the advanced mathematical calculations of crime-solving university professor Charlie Epps. By following this tradition, Sherlock ties itself to the forensic crime genre category and thus asserts its contemporaneity, which further distinguishes it from previous Holmesian texts.

However, the fact that Sherlock follows so closely in the footsteps of the forensic crime dramas also poses a problem: it threatens to render its hero commonplace. While the Victorian-era Holmes is celebrated as the very first 'scientific detective', a present-day version competes with legions of modern forensic experts. This problem is discussed in several of the paratexts surrounding Sherlock (Gatiss, 2010; Pierce 2010; Gilbert 2011; Yap 2011; Unlocking Sherlock, PBS, 2014). This line of enquiry was apparently already anticipated even before the first episode aired, as indicated by a promotional blog-post on BBC's website in which Mark Gatiss (2010) argued that:

[Sherlock Holmes] can't possibly wear a paper forensic suit or it's all too CSI. And what about that? Doyle virtually invented forensic detection. How can Sherlock exist in a world where the police do all the finger-printing, criminal profiling and analysis that were once his unique attribute? 
Interestingly, in the 60-minute unaired pilot of Sherlock that was initially created to be the first episode of the series (it roughly follows the same plot as 'A Study in Pink'), Holmes does put on a 'paper forensic suit' when first visiting a crime scene together with John. $\mathrm{BBC}$ asked the producers to reshoot the episode after deciding to instead commission Sherlock in the format of three 90-minute episodes and a comparison between the two versions also indicates a need to distinguish Holmes more clearly from his crime-solving peers. Gatiss has, for example, explained that they decided to let Holmes keep his dramatic Belstaff coat on during the crime scene investigation because they realised he looked 'ridiculous' in the forensic suit (Gilbert 2011). The fact is that most people look ridiculous in the blue one-piece protective gear worn by UK forensic crime scene investigators, which makes Holmes stick out as far more dignified and stylish than Lestrade, Watson and all other law enforcement personnel around.

Whereas the 'Pilot' version of this scene primarily demonstrates Holmes and Watson's instant and effortless partnership (the two are visually mirrored throughout the scene and Holmes asks for Watson's advice before making his own deductions), 'A Study in Pink' makes a far bigger deal out of showcasing Holmes' almost super-human deductive skills. John and Lestrade both remain in the far end of the room while Holmes alone takes control over the crime scene, looming over the corpse while firing off deductions. He only invites Watson to examine the body towards the end of the scene and simply does so to prove his ability to make Lestrade break protocol, not because he is interested in John's opinion. Furthermore, when Lestrade's resident forensic scientist - Philip Anderson - attempts to enter the crime scene Holmes resolutely shuts the door in his face. A number of subtle shifts in costume, blocking and performance are thus used to identify Holmes as something Other than the police officers, medical examiners and forensic experts of the modern era.

Holmes does occasionally make use of forensic methods to solve crimes. For example, in 'The Great Game' (S01E03) he analyses traces of mud and pollen in a microscope and in 'The Reichenbach Fall' (02E03) he performs a chemical analysis on linseed oil left at the scene of a kidnapping. The programme also repeatedly alludes to scientific experiments that Holmes performs in his 'spare time' (the kitchen at 221b Baker Street is often filled with chemical equipment and assorted body parts). However, these more hands-on scientific methods are not given the extended screen-time or spectacular visual portrayal one has come to expect from a forensic crime drama. Instead, the programme puts far more effort into constructing Holmes' deductions as the most important, unique and spectacular aspect of his crime-solving process. As Gatiss (2010) concludes in his blog, this modern-day Holmes remains unique because:

[In] our version anyway, [he] is still, and always, the best and wisest man there is. The police may be able to put clues together, but only Sherlock has the vast brain power and imagination that can make the huge leaps of deduction.

In other words, it is Holmes' pure cerebral skills - his ability to observe, deduct, and interpret - that the programme ultimately presents as his main distinguishing feature. In addition the visually innovative depiction of digital technology, the programme's most spectacular and inventive special effects are reserved for visualisations of Holmes' thought process. Over Sherlock's first three series and the subsequent Christmas Special the deduction sequences are 
kept visually exciting by ever-changing combinations of extreme close-ups, unconventional angles, dynamic camera-movements, imaginative match-cuts, fast-paced editing and a wide variety of graphic superimposed elements.

Sherlock does place much visual and narrative importance on the range of digital aids that Holmes regularly uses to find information and establish facts, but this contributes to a more general analogy between its hero's mind and digital technology that ultimately constructs the cerebral approach as better than the contemporary forensic methods celebrated in forensic crime dramas. Sherlock continuously evokes the 'brain-as-computer' metaphor that dominated thinking about the human brain during the second half of the twentieth century (Elman 2001, 295-96; Baake 2003,134-39): Holmes refers to his own mind as his 'hard drive' and many of the deduction sequences draw on digital aesthetics to visualise Holmes' thought process as similar to database searches, digital maps and surveillance cameras. Furthermore, the programme's characteristic superimposed graphic effects are utilised in similar ways for both the deduction sequences and the onscreen display of text messages, e-mails and database searches. Particularly over time, the digital technologies used by Holmes become understood as extensions of his already extensive mind, thus rendering him better beyond technology. Hence, while Holmes' digital know-how definitely distinguishes him from previous incarnations of Sherlock Holmes (Hills 2012, 27-29; Kustritz and Kohnen 2012, 94-97), it is his old-fashioned brainpower that makes him stand out in the contemporary crime drama landscape.

Furthermore, in the second series episode, 'The Hounds of Baskerville', Sherlock introduces the concept of Holmes' 'mind palace', described as 'a memory technique, a sort of mental map' that allows him to 'never forget anything'. This technique, which is also known as the method of loci or the memory palace technique (Bower 1970), provides a framework for understanding Holmes' deduction process spatially, which justifies the programme's onscreen visualisations of his thought process. The mind palace metaphor has grown increasingly prominent since 'The Hounds of Baskerville'. The deductive sequences in the third series repeatedly transfer Holmes (and occasionally the other characters) into expressionistically depicted imaginary spaces (identified as part of his the mind palace) and we also find out that Holmes' new archenemy - the blackmailing media mogul Charles Augustus Magnussen - has his very own mind palace. The Christmas Special, 'The Abominable Bride', goes even further by situating a vast majority of its screen-time inside Holmes' mind. In order to figure out how Moriarty could still pose a threat in spite of having obviously committed suicide, Holmes retreats into his mind palace to solve a similar case from 1895 (together with imaginary nineteenth century versions of the other recurring characters) and only a couple of brief scenes are actually set in 'the real world'. By visualising Holmes' mind in such a concrete and spectacular manner, Sherlock places an increasing emphasis on its hero's highly imaginative deductive process. This stages a significant break from the conventions of previous forensic crime dramas, which typically constructed the forensic approach as one eliminating fanciful interpretations and relying on strictly scientific and technological analyses.

In spite of the programme's initial assertion that Holmes' cerebral abilities means that he lacks in empathy and social skills, the mind palace sequences affiliates him with another conventional type of cerebrally inclined crime solving hero: the 'criminal psychologist' familiar from profiling shows such as Cracker (ITV, 1993-1996, 2006), Profiler (NBC, 1996- 
2000), Millennium (Fox, 1996-99) and Criminal Minds (CBS, 2005-). Profiler and Millennium both featured expressionistic fantasy sequences that illustrated their profilers' abilities to empathically access the mind-set of the killer. The similarities between this generic tradition and Sherlock's increasingly elaborate mind palace sequences is highlighted by the way in which another innovative television adaptation, Hannibal (NBC, 2013-15), marries these two visualisation technics. In reimagining Thomas Harris' seminal novels about the FBI profiler Will Graham and the serial killer Dr. Hannibal Lecter, Hannibal initially followed in the footsteps of Profiler and Millennium by depicting Graham's empathic crime solving technique through expressionistic, but fairly brief, fantasy sequences. However, these imaginary spaces extended exponentially from season two as the concept of the 'mind palace' was introduced, presented as a method used by Dr. Lecter to escape his physical surroundings into a world of his memories and imagination. Not unlike Holmes' efforts to solve a case entirely in his own mind in 'The Abominable Bride', the third season of Hannibal consists of frequent and lengthy sequences where Dr. Lecter and Will Graham face-off inside their mind palaces in an extended mental struggle (and courtship).

\section{Subverting the Modern Forensic Expert}

In order to reinforce that Holmes are both different from, and better than, today's forensicsavvy law enforcement, the programme also stages an almost burlesque portrayal of the modern-day forensic expert. The figure of the forensic expert is primarily represented by Anderson, but also to some extent by Molly Hooper, a specialist registrar working at the morgue in St. Bartholomew's Hospital. Both these characters are frequently used for comic relief, using humour that is partly produced by a subversion of the dominant conventions for depicting forensic scientists and medical examiners on television. Sherlock does not simply go against the grain of the expectations tied to previous forensic crime dramas. More specifically, it draws on some of the wildly circulated critiques against the forensic crime genre's unrealistic portrayal of forensic experts, which Sherlock references in order to exchange one type of crime-solving hero for another.

Holmes' refusal to wear the protective gear in the crime scene investigation sequence in 'A Study in Pink' is one example of the programme's complex play with genre expectations. The fact that he insists on keeping his iconic coat on actually follows the tradition of costume design established by US forensic crime dramas, particularly those belonging to the CSI franchise. As numerous reviews and popular articles on the forensic subgenre show, these programmes are widely known for portraying their heroes with ample glamour (Gold 2006; Bostrom 2006; Zimonjic 2006; McDonald 2009; Henley 2012). The forensic scientists wear fashionable civilian clothes even when processing messy crime scenes and attending gory autopsies. By comparison, Sherlock's Anderson appears decidedly unglamorous in his forensic suit and unfashionable haircut. The same could be said for Molly Hooper, who characteristically combines her lab coat with girly cardigans, buttoned-up floral blouses and sensible shoes.

To some extent, Anderson's and Hooper's more mundane appearances seem to answer the calls for more realistic portrayals of forensic scientists that has characterised much of the forensic crime genre's reception in the media since the mid 2000s. One telling and representative example is a 2006 interview with crime scene investigator Beth Troutman for The Wilmington Morning Star, in which the journalist makes sure to emphasise her plain 
appearance (blond hair 'tethered into a neat French twist') and sensible clothing (a blue polyester uniform), before quoting Troutman who further asserts that she does not wear her own clothes to work due to all the 'dumpster-diving' and that the CSI franchise appear as 'comedy' to her (Bostrom 2006). This kind of inadvertent critique is central to the wider media debate on the so-called 'the CSI effect' that flourished across the US and Europe during the mid 2000s, for example discussing the damaging impact that the glamorous and unrealistic portrayal of forensic science might have on the American legal system. As Craig M. Cooley summarises, news reports on the CSI effect have specifically expressed worries that faithful television viewers would overestimate the speed and of the forensic process, as well as blindly assume that: '(1) crime labs are pristine scientific sanctuaries, which always have to most up-to-date forensic technology; (2) crime labs only employ the most skilled and imaginative 'scientists' who make few, if any, errors' (Cooley 2006-07, 471-4).

Convincing academic studies have argued that this debate must be primarily understood as a self-reflexive media discourse (Cole and Dioso-Villa 2006-07; Podlas 2006; Bricknell 2008; Steenberg 2013, 101-124). However, the intense media coverage about the genre's unrealistic portrayal of forensic science might in itself have had an impact on viewer expectations, circulating ideas about the drab reality of forensic investigations. When Sherlock puts Anderson in protective gear and Hooper in frumpy girl-next-door clothes, it calls upon the viewers' pre-existing knowledge that this is supposedly what forensic scientists actually look like in real life. In the context of UK television, this move is by no means new: British forensic crime dramas like McCallum, Silent Witness and Waking the Dead have generally aspired to depict forensic scientists in a more 'realist' style that adheres somewhat closer to actual forensic protocols. In these cases the blue forensic suits create a sense of realism that is no doubt intended to construct the figure of the forensic scientist as a reliable and down-toearth crime-solver. However, Sherlock conversely enhances the negative connotations already tied to the notion of real-life forensic science in the post-CSI-effect culture, which also constructs the forensic method as slow, bureaucratic, and unreliable.

Anderson's refusal to collaborate with Holmes because it breaks protocol marks him as a stickler for rules, which engages with the idea that the forensic apparatus is actually bureaucratic and inefficient in real life (much unlike the well-oiled machinery depicted on CSI or Bones). Holmes continuously gets told off for contaminating crime scenes, but because there are never any adverse consequences of his tendency to break the rules (he always solves the crimes) these policies come across as unnecessary obstacles hampering the speed of the investigation. The forensic method is constructed as an excessively dull and monotonous process that places more importance on the collection and cataloguing of physical evidence than on the analysis of what these traces actually mean. As Steven Moffat has pointed out in an interview, what differentiates Holmes from the forensic scientists on CSI is his lack of interest in 'the gathering of information' (Gilbert, 2011). In the behind-the-scenes documentary Unlocking Sherlock (PBS, 2014), Jonathan Aris - the actor who plays Anderson - similarly argues that:

Sherlock Holmes in the modern day really has departed from forensic science. $\mathrm{He}$ knows it all, he's absorbed it, but what is striking about him is where he leaves it behind and makes these incredible deductive leaps. Whereas [with] Anderson it's all about method and process, and that can only take you so far in a certain direction. 
Hence, the programme and its makers continuously suggest that the traditional forensic method fails to produce swift and informative interpretations of the evidence collected. For example, in 'The Blind Banker' (S01E02) Holmes instantly surmises that what looks like a suicide is in fact a murder, while the inspector working on the case insists they have to do a ballistics test to confirm this theory before they can begin a murder investigation. After much wasted time, Holmes is of course proven right, prompting him to proclaim: 'This investigation might move a bit quicker if you took my word as gospel.'

The official brand of forensic science is similarly depicted as often resulting in unimaginative and sometimes even faulty conclusions. In contrast to his pompous and self-satisfied attitude, Anderson continuously interprets evidence in ways that are simplistic or outright inaccurate. For example, in 'A Study in Pink', Anderson assumes that a victim has written the German word for revenge ('Rache') before she died, while Holmes rightly surmises that she was in fact attempting to write the name of her dead daughter ('Rachel'): the password for her smartphone. The gravity of Anderson's incompetence has increased significantly over the three series. In 'The Reichenbach Fall', a majority of the forensic evidence has been planted by Moriarty in order to incriminate Holmes, a ruse that has Anderson completely duped. Furthermore, in the third series Anderson has lost his job and is now convinced that Holmes faked his own death; he has even started a fan club dedicated to figuring out how Holmes 'did it'. While Anderson is right about Holmes still being alive, 'The Empty Hearse' dedicates considerable screen-time to staging the fan club's decidedly wacky theories about his survival. Towards the end of the episode Anderson suffers a melodramatic mental breakdown when realising he will never be able to figure out what actually happened. 'The Empty Hearse' also has Anderson using his forensic know-how to (unsuccessfully) stage a crime scene as a kind of gift to Holmes. All these antics further serve to celebrate Holmes' deduction process as, by comparison, producing highly sophisticated, creative and useful interpretations.

While Anderson's incompetence is illustrated in the extreme, Molly Hooper is more complex character. On the one hand, Sherlock has been criticized by its fans for portraying her as a hyper-feminine, shy and love-struck girl whose primary aim is to win Holmes' affections and provide emotional support, yet she is continuously ignored and even mistreated by him (Meadows 2011; ineffable-hufflepuff 2013; Raizendarose 2015). As a female morgue attendant, Hooper is derivative of programmes such as Silent Witness, CSI: Miami, and Crossing Jordan, all of which feature female medical examiners. As Lindsay Steenberg has discussed in detail, the figure of the female expert investigator emerged on television in tandem with the forensic turn in the mid-1990s (Steenberg 2013, 50-73). Hooper's sensitivity and kindness follows the tradition of depicting female experts as highly empathic and intuitive crime-solvers (Steenberg 2013, 63-67). However, most of Hooper's forerunners including Dr Sam Ryan in Silent Witness, Dr Jordan Cavanaugh in Crossing Jordan, Catherine Willows in CSI and Dr Temperance Brennan in Bones - are also characteristically portrayed as extremely dedicated career women who willingly sacrifice their private lives in order to solve crimes. While Holmes himself is a similarly dedicated investigator, Hooper's focus is continuously compromised by her emotions for him. In 'The Great Game' it drives her to unknowingly date Moriarty and in 'The Empty Hearse' she is ultimately unable to take up Watson's role as Holmes' main crime-solving companion because her heartbreak makes it too difficult to be around him. This subversion of the female expert investigator could be said 
to further serve to undermine the modern forensic approach for the benefit of the cerebral gentleman detective.

However, Hooper has, on the other hand, also been widely celebrated by female fans as a positive 'role model' that makes young women feel like a future career in medicine or science is attainable even for someone with low self-esteem. She does repeatedly prove herself a more competent and useful scientist than Anderson and her fans tend to further emphasise her professional status, which, for example, is indicated by the way many fan-made guides to Molly Hooper 'cosplay' put particular stress on the items in her costume that signifies her occupation: her lab coat, white latex gloves, different kinds of protective gear, and St Bart's Hospital ID badge. Furthermore, considering the numerous online 'how to dress like Molly Hooper'-guides it is obvious that many viewers see Hooper's overall wardrobe as desirable rather than unglamorous; something which can partly be explained by the wider 'geek-chic' movement engendered by the success of shows such as The Big Bang Theory (CBS, 2007-). Furthermore, in the third series Hooper develops into a more significant figure, which is part of a general development whereby the show becomes more explicitly critical against Holmes' antisocial behaviour and shifts its focus towards the emotional relationship between the characters. Alongside Watson and Lestrade, Hooper emerges more clearly as one of Holmes' emotional guides, teaching him that friendship, kindness and consideration are valuable character traits. However, it is significant that the main reason why she 'matters' is her caring nature, not her skills as a forensic scientist.

\section{The Consulting Detective as Establishment Watchdog}

Another way in which Sherlock undermines the modern forensic approach is by implicitly identifying the crime lab as one of several major institutions in society that can be criticised for being inefficient, unethical or corrupt. The programme's revival of the gentleman detective is further supported by figuring Holmes as a kind of 'watchdog' whose cerebral prowess not simply allows him to catch individual criminals, but also expose ills within a number of institutions that he himself, as an independent 'consulting detective', remains detached from.

The programme's derogatory portrayal of the figure of the forensic scientist is part of a wider critique of the regular law enforcement. In this Sherlock follows faithfully in the footsteps of Doyle's original stories, which already portrayed Sherlock Holmes' relationship to the police force as antagonistic. On the one hand, the programme portrays Holmes' main contact at the police, Inspector Lestrade, as a genuinely good man who treats the detective with respect and kindness and is willing to put aside his own pride in order to ensure the cases are solved. But on the other hand, Lestrade is also depicted as a decidedly mediocre crime investigator. For example, in 'A Scandal in Belgravia' (S02E02) Holmes tells Lestrade that his wife is having a secret affair with a PE teacher, which serves to illustrate his inferior skills of observation.

Lestrade's colleagues are, however, shown in even worse light. Both Detective Sergeant Sally Donovan and DI Dimmock openly distrust Holmes and stupidly refuse to listen to his advice, which slows down several investigations. Donovan, a recurring character throughout seasons $1-3$, is not only portrayed as narrow-minded, but also as an outright bully whose distain for Holmes makes her susceptible to Moriarty's trickery. In 'The Reichenback Fall' (S02E03), Donovan and Anderson are both manipulated by Moriarty into believing that Holmes has staged a number of spectacular cases to gain attention, which results in Holmes being forced 
to stage his own suicide and leave the country in order to keep his friends safe. The police force is thus revealed as an institution struggling with incompetence, inefficiency and intolerance.

The antagonistic relationship between the police force and Holmes not only marks the programme as faithful to Doyle's original stories, it also forms the basis for another contradictory genre linkage to earlier forensic crime dramas. The criminalists and scientist investigators of programmes such as CSI, Bones and Numb3rs are occasionally depicted as having similarly tense relationships with other law enforcement personnel. In CSI, Gil Grissom (the head of the night shift team at the Las Vegas crime lab) has a long-running conflict with Conrad Ecklie, who initially runs the day shift and is later promoted to Undersheriff. The conflict is rooted in Ecklie's lack of devotion to objective science, unlike Grissom he is acutely aware of the politics of the wider law enforcement and is willing to compromise the scientific integrity if it serves his own ambition. The fact that he later takes up a position within the actual police force is indicative of this programme's wider distrust for law enforcement careerists. The tension between the police and the criminalists reaches a pinnacle at the end of Season 8, when Undersheriff McKeen murders crime science investigator Warwick Brown in an attempt to cover up the ties between the LVPD and the mafia that the forensic scientists had been investigating.

However, in comparison with many crime dramas of the late 1980s and early 1990s that placed much emphasis on exposing problems within the police force and did not shy away from examining the accountability of their often flawed investigators (Brunsdon 1998, 225228 ), the forensic crime dramas of the late 1990s and 2000s generally encouraged its viewers to once again trust the official systems of policing as reliable institutions. After Warwick's death his colleagues managed to swiftly expose the corruption within the LVPD: one of numerous examples where the criminalists are constructed as a defence against corruption within the law enforcement. Hence, although the forensic scientists of programmes such as CSI, Bones or Numb3rs are often depicted as working within institutional contexts that are, at least in part, separate from the police departments they collaborate with (i.e. 'The Las Vegas Crime Lab', 'The Jeffersonian Institute' or 'The Californian Institute of Science'), their scientific approach is presented as a safeguard that injects the entire legal system with a renewed sense of trustworthiness by guaranteeing reliability and objectivity.

While Sherlock's portrayal of its hero's relationship with the police articulates genre linkages to earlier forensic crime dramas, it is also fundamentally different. The resurrection of the figure of the singular gentleman detective implies that forensic science has done little to actually better the official law enforcement; on Sherlock the police are still generally 'a bad lot' (Doyle 2011, 31) and only an autonomous consulting detective can provide the public with a sense of security. As a post-CSI crime drama Sherlock engenders a genre development that stages a nostalgic return to a pre-CSI $19^{\text {th }}$ Century version of the independent investigator. In other words, this is a programme that pushes beyond the forensic turn by actually moving backwards past it.

The difference between the generic forensic scientist, as a figure that mends the system from within, and Holmes, as a truly independent watchdog, becomes even more apparent if one also compares CSI and Sherlock's portrayals of unethical, and even criminal, uses of science or medicine. The Sherlock episode 'The Hounds of Baskerville' (S02E02) revamps the 
familiar plot of The Hound of Baskerville's (Doyle 2007), which famously deals with inheritance fraud and mistaken identity, into a bioethical tale about government experiments in genetics, biomedicine and chemical warfare at a secret military research facility on Dartmoor called Baskerville. Henry, a young man who is convinced his dad has been killed by a huge genetically manipulated dog, contacts Holmes and Watson to investigate the experiments taking place at Baskerville. The television viewers are initially made to suspect a female genetic engineer: Dr Stapleton. For most of the episode she is portrayed using iconography associated with the popular mythology surrounding the character of Dr Frankenstein, originally appearing in Mary Shelley's 1818 novel Frankenstein; or, The Modern Prometheus (Shelley 2007). She is presented as an arrogant scientist who is removing, splicing and recombining genes indiscriminately 'just because she can'. Eventually we find out that she is only guilty of having accidently given her daughter a genetically manipulated rabbit, only to ruthlessly take it away. The real culprit is her colleague Dr Frankland (whose name is suitably similar to that of Dr Frankenstein), who murdered Henry's father in a cloud of hallucinatory gas to stop him from exposing his unethical experiments in chemical warfare.

At first sight this episode is not too dissimilar from the many episodes of CSI that feature doctors and scientists who commit crimes, which in extension highlights that the science used by the forensic investigators could also become implements for unethical acts in the hands of the wrong people. Such 'criminal scientists' included, amongst many others, the unlicensed sex change surgeon Dr Benway in 'Ch-Ch-Changes' (S05E08), the failed coroner Dr Shaw in 'The Gone Dead Train' (S09E22), the serial killing dentist Dr Lowry in 'Sweet Jane' (S09E06) and the failed medical school student 'Dr Jekyll', who the forensic scientists hunt throughout season ten of CSI.

There is, however, one significant difference between CSI's and Sherlock's treatment of criminal scientists. In 'The Hounds of Baskerville' Sherlock specifically critiques scientists that represent the Foucauldian notion of 'biopower' (Foucault 2003, 239), i.e. science being used by state institutions to assert control over the population, whereas CSI consciously and carefully avoids this particular bioethical issue. Even though power over the health of large groups of people is now largely held by large capitalist corporations (Rose 2007, 31-39), anxieties about state endorsed biopower are still circulating widely (Salter and Jones 2002; Koch 2004; McWorther 2009). This is not surprising considering the widespread rise of neoliberal trends, which generally clash with the idea of an active and powerful state apparatus (Foucault 2009, 317-19; Rose 2007, 6-7). This cultural unease tends to recollect the versions of biopower practiced by totalitarian regimes like Hitler's Germany or Stalin's Russia (Foucault 2003, 259; Rabinow and Rose 2006) and 'The Hounds of Baskerville' tellingly references cultural imagery that, following the end of the Second World War, has precisely been tied to scientific experiments of the Nazi government. In this episode Holmes' investigation deconstructs a state-of-the art government facility and reveals it as reminiscent to the types of laboratories traditionally seen in horror films about Nazi scientists, from The Frozen Dead (Herbert J. Leder, 1966) and Shock Waves (Ken Widerhorn, 1977) to more recent examples such as The Bunker (Rob Green, 2001) and Outpost (Steve Barker, 2007). Sherlock thus suggests that there is a fine line between historic misuses of biopower and new state-funded biomedical research. The 'official version' of Baskerville, which showcases its shiny facilities, high-tech microscopes and scientists in spotless lab coats, is continuously undermined by recurrent unsettling inserts of warning signs, old machinery and caged test 
animals - including a monkey doing a Nazi salute. By staging a state-sanctioned institution of science as a site for unethical experiment and murder, Sherlock further defends the need to resurrect the figure of the autonomous gentleman detective as a watchdog against the corrupt institutions of contemporary society.

Conversely, CSI always portrayed its criminal scientists as amateur practitioners that lacked official credentials and predominantly acted outside any established institution. Instead of investigating flaws in any official scientific institutions - the crime lab itself being one - CSI is thus sure to deflect any bioethical worries away from the law enforcement and transfer them onto the figure of the crazed and anti-social criminal. By asserting that the problem of unethical medico-scientific practices are limited to individual offenders acting outside the system, CSI circumvents the notion that an exploitative, corrupt version of biopower belongs to the state. In comparison with the criminal scientists, the forensic investigators come across even more forcefully as well-educated, humble and heavily regulated government employees who will provide a system for scientific policing that is ethically sound, transparent and officially legitimised. All this in spite the fact that the crime lab could be blamed for being a state institution that precisely use science for the surveillance and policing of populations (Broe 2004; Bonnycastle 2009; Hausken 2014). According to CSI, biopower can be responsible managed for the greater good of society with the help of ethically conscious forensic scientists.

CSI's and Sherlock's different takes on unethical science actually share a similar utility, namely, to assert the necessity of their respective heroes: the team of civil servant scientists and the autonomous cerebral detective. Balaka Basu has argued that the Sherlock's portrayal of its main character as a modern-day consulting detective renders his practice 'a triumph of the free market and the private sector; he performs all tasks better than the public servants who are employed by the State' (Basu 2012, 205). However, even though the program does feature harsh portrayals of public sector employees such as Anderson, Donovan and Mycroft (who possesses the same cerebral powers as his brother, but uses them to secretly run the British government in his role as a civil servant), I would not exactly describe Sherlock's political stance as coherently neo-liberal. For one thing, the programme is careful to continuously note that Holmes is completely uninterested in solving crimes for a profit (Watson is, seemingly against his will, repeatedly forced to take on extra work at clinics for money). Taking into account all three seasons, the programme positions its hero against stategoverned and corporate institutions alike. For example, in 'The Blind Banker' it takes jabs at the banking sector and 'His Last Vow' (S03E03) places the press under scrutiny though an extraordinarily unsympathetic portrayal of Charles Augustus Magnussen, who Holmes goes after simply because 'he attacks people who are different and prays on their secrets'. Sherlock thus asserts that most of the institutions of power in society are in need of being deconstructed and only a truly independent detective, with an exceptional mind, can do so.

\section{Concluding Remarks}

Sherlock's contradictory relationship to the conventions associated with the forensic crime genre category is a telling example of how the television industry simultaneously renews and recycles generic elements in a continuous quest to appear both current and familiar. Sherlock can be understood as a post-CSI crime drama that is deeply influenced by the forensic crime dramas of the late 1990s and 2000s, while at the same time rejecting and subverting many of 
the forensic subgenres' central tropes. In part, my genre study supports Basu's argument that Sherlock 'displays a retrofuturism that imagines the present solely in terms of the future of an outdated past' (Basu 2012, 197). The programme's narrative and visual focus on digital technologies functions much like a veneer for its nostalgic desire to resurrect the figure of the gentleman detective. Sherlock moves forward beyond the forensic turn on television by, in some ways, moving backwards. The programme's efforts to assert its hero's exceptionality constructs Holmes as a cerebral crime-fighter who prefers the mind palace to the modern crime lab, which in some ways makes him an even more conservative crime fighter than Doyle's Sherlock Holmes, whose scientific approach was cutting-edge at the time.

Sherlock's subversion of the figure of the modern forensic scientist indicates that the forensic crime genre category has not only entered the mainstream, but is also increasingly considered something of the (recent) past. Another sign that televisual forensics has gone out of style is CBS's launch of a new CSI spinoff titled CSI: Cyber (CBS, 2015). Rather than depicting crime scene investigators, medical examiners and forensic scientists that collect physical evidence, perform autopsies and conduct scientific analyses, CSI: Cyber focuses on the work of 'CyberPsychologist' Special Agent Avery Ryan who solves 'illegal activities that start in the mind, live online, and play out in the real world' (Andreeva 2014). The CSI franchise has thus moved towards a similar type of retrofuturism as that of Sherlock; it too attempts to move forward by backtracking. The show's narrative and visual focus on digital technology is an obvious attempt to re-assert the franchise's reputation for being cutting-edge, but the technological wizardry largely functions as a superficial justification for resurrecting the figure of the criminal psychologist. While Agent Ryan has specialist knowledge of hard drives and 'the dark net', it is her ability to understand the psychology behind the perpetrators' acts that enables her to solve the 'cyber crimes' that initially baffle her colleagues at the Las Vegas Crime Lab. Furthermore, the casting of Patricia Arquette as Agent Ryan implicitly lends an element of the uncanny to the character, carried over from her previous appearance as a psychic investigator in Medium (NBC/CBS, 2005-11), which also encourages us to recall how Profiler and Millennium tended to stage their profilers' emphatic abilities as bordering on the paranormal. Hence, CSI: Cyber has joined Sherlock in attempting to move beyond the crime drama mainstream by presenting us with a retrofuturistic investigator with an exceptional mind and little interest in physical evidence.

\section{Bibliography}

Andreeva, Nellie. 'CBS 2014 Schedule: Monday Comedy Block Trimmed, "NCIS: New Orleans" Gets Post-"NCIS" Slot, "NCIS: LA" to Monday, "CSI" to Sunday, "The Amazing Race" to Friday', Deadline Hollywood, May 14, 2014, http://www.deadline.com/2014/05/cbsfall-schedule-2014-upfronts-new-shows/. (Accessed 28 January 2016.)

Baake, Ken. Metaphor and Knowledge: The Challenges of Writing Science. Albany: State University of New York Press, 2003.

Basu, Balaka, 'Sherlock and the (Re)Invention of Modernity' in Louisa Ellen Stein and Kristina Busse (eds.) Sherlock and Transmedia Fandom: Essays on the BBC Series, Jefferson and London: McFarland \& Co, 2012, 196-209. 
Blake, Meredith. 'HBO's 'True Detective' with Harrelson, McConaughey is an unusual case', Los Angeles Times, January 03, 2014.

http://articles.latimes.com/2014/jan/03/entertainment/la-et-st-ca-preview-true-detective20140105/2. Accessed 28 January 2016.

Bochman, Svetlana. 'Detecting the Technocratic Detective', in Lynnette Porter (ed.) Sherlock Holmes for the $21^{\text {st }}$ Century: Essays on New Adaptations, Jefferson and London: McFarland \& Co, 2012, 144-154.

Bonnycastle, Kevin Denys. 'Not the Usual Suspects: The Obfuscation of Political Economy and Race in CSI' in The CSI Effect: Television, Crime and Governance, Michele Byers and Val Marie Johnson, eds. Plymouth, Lexington, 2009, 149-176.

Bostrom, Majsan. 'On the trail; CSI work takes grit, lacks TV glamour, investigator says', Wilmington Morning Star, 28 May 2006, 1.

Bower, Gordon H. 'Analysis of a Mnemonic Device: Modern psychology uncovers the powerful components of an ancient system for improving memory', American Scientist 58(5), 1970, 496-510.

Brickell, Wendy. 'Is It the CSI Effect or Do We Just Distrust Juries', Criminal Justice 23(2), 2008, 10-17.

Broe, Dennis. 'Genre Regression and the New Cold War: The Return of the Police Procedural’ Framework, 45:2, Fall 2004, 81-101.

Brunsdon, Charlotte. 'Structure of Anxiety: Recent British Television Crime Fiction', Screen, 39:3 Autumn, 1998, 223-243.

Caldwell, John Thornton. Televisuality: Style, Crisis, and Authority in American Television (New Brunswick, NJ: Rutgers University Press, 1995.

Cole, A. Simon and Rachel Dioso-Villa. 'CSI and its effects: Media, juries, and the burden of proof’, New England Legal Review, Vol. 41, 2006-2007, 435-520.

Cooley, Craig M. 'The CSI Effect: Its Impact and Potential Concerns', New England Legal Review, Vol. 41, 2006-07, 471-502.

Coppa, Francesca. 'Sherlock as Cyborg: Bridging Mind and Body' in Louisa Ellen Stein and Kristina Busse (eds.) Sherlock and Transmedia Fandom: Essays on the BBC Series, Jefferson and London: McFarland \& Co, 2012, 210-223.

Doyle, Arthur Conan. A Study in Scarlet, London: BBC Books, 2011.

Doyle, Arthur Conan. The Hound of Baskerville, London: Penguin, 2007. 
Elman. Jeffrey L. 'Connectionism and Language Acquisition', in Michael Tomasello and Elizabeth Bates (eds.) Language Development: The Essential Readings, Oxford: Blackwell, 2001, 295-306.

Evans, Elizabeth Jane. 'Shaping Sherlocks: Institutional Practice and the Adaptation of Character' in Louisa Ellen Stein and Kristina Busse (eds.) Sherlock and Transmedia Fandom: Essays on the BBC Series, Jefferson and London: McFarland \& Co, 2012, 102-117.

Foucault, Michel. Society Must be Defended: Lectures at the Collège de France 1975-76 (London: Allen Lane/Penguin, 2003).

Foucault, Michel. The Birth of Biopolitics: Lectures at the Collège de France 1978-1979 (Basingstoke: Palgrave Macmillan, 2009).

Gatiss, Mark. 'Sherlock: For Holmes and Watson, The Game is Afoot', BBC TV blog, 23 July 2010, http://www.bbc.co.uk/blogs/tv/2010/07/sherlock.shtml. (Accessed 28 January 2016).

Gere, Charlie, 'Reading the Traces' in Reading CSI: Crime TV Under the Microscope, ed. Michael Allen (London: I.B. Tauris, 2007), 129-139.

Gilbert, Gerard. 'The return of Sherlock Holmes', The Independent, 9 December, 2011, 4.

Gold, Matea. 'L.A.'s crime fighters in lab coats; Spinoff of Court TV's 'Forensic Files' aims for drama, but can real-life science compete with the glamour of a 'CSI'?', Los Angeles Times, 31 March, 2006, 2.

Graham, Anissa M. and Jennifer C. Garlen. 'Sex and the Single Sleuth' in Lynnette Porter (ed.) Sherlock Holmes for the $21^{\text {st }}$ Century: Essays on New Adaptations, Jefferson and London: McFarland \& Co, 2012, 24-34.

Harrington, Ellen Burton, 'Nation, Identity and the Fascination of Forensic Science in Sherlock Holmes and CSI', International Journal of Cultural Studies, Vol. 10(3), 2007, 365382 .

Harrington, Ellen Burton. 'Terror, Nostalgia, and the Pursuit of Sherlock Holmes in Sherlock' in Louisa Ellen Stein and Kristina Busse (eds.) Sherlock and Transmedia Fandom: Essays on the BBC Series, Jefferson and London: McFarland \& Co, 2012, 70-84.

Hausken, Liv. 'Forensic Fiction and the Normalization of Surveillance' Nordicom Review 35:1, 2014, pp. 3-16.

Henley, Jon. 'Welcome to CSI: Oxford', The Guardian, 18 January 2012, 9.

Hills, Matt. 'Sherlock's Epistemological Economy and the Value of 'Fan' Knowledge: Hote Producer-Fans Play the (Great) Game of Fandom', in Louisa Ellen Stein and Kristina Busse (eds.) Sherlock and Transmedia Fandom: Essays on the BBC Series, Jefferson and London: McFarland \& Co, 2012. pp 27-40. 
Ineffable-Hufflepuff. 'Fandoms and Feminism: I'm amazed at people who fail to see the issue with how Sherlock treats women', 31 July 2013.

http://fandomsandfeminism.tumblr.com/post/54830589800/thorntonoakenshieldconstantlyrambling (Accessed 28 January 2016.)

Koch, Lene. 'The Meaning of Eugenics: Reflections on the Government of Genetic Knowledge in the Past and Present', Science in Context, 17(3), 2004, 315-331.

Kompare, Derek. CSI (Malden: Wiley-Blackwell, 2010).

Kustriz, Anne and Melanie E. S. Kohnen. 'Decoding the Industrial and Digital City: Visions of Security in Holmes' and Sherlock's London' in Louisa Ellen Stein and Kristina Busse (eds.) Sherlock and Transmedia Fandom: Essays on the BBC Series, Jefferson and London: McFarland \& Co, 2012, 85-100.

La Paz, Ana E. 'Making the Transition: The Modern Adaptaton and Recreation of the Scientist Detective Hero' in Lynnette Porter (ed.) Sherlock Holmes for the $21^{\text {st }}$ Century: Essays on New Adaptations, Jefferson and London: McFarland \& Co, 2012, 81-92.

Lampert, Nicole. 'I felt more exposed than I've ever been' Elisabeth Moss, Mad Men's Peggy Olson, on her steamy alfresco scenes in this summer's hot new BBC thriller', Mail Online, 12 July 2013, http://www.dailymail.co.uk/femail/article-2361716/Elisabeth-MossMad-Mens-Peggy-Olson-steamy-alfresco-scenes-summers-hot-new-BBC-thriller.html. (Accessed 28 January 2016)

Lury, Karen. Interpreting Television (London: Hodder Arnold, 2005).

McDonald, Barry. 'Why can't we get CSI: Bishopbriggs?', Glasgow Evening Times, 28 July 2009, 24.

McWorther, Ladelle. 'Governmentality, Biopower, and the Debate over Genetic Enhancement', Journal of Medicine and Philosophy, 34, 2009, 409437.

Meadows, Foz. 'Sexism in Sherlock', 12 December 2011, https://fozmeadows.wordpress.com/2011/12/12/sexism-in-sherlock/ (Accessed 28 January 2016).

Mittell, Jason. Genre and Television: From Cop Shows to Cartoons in American Culture (New York and London: Routledge, 2004).

Pierce, Scott D. 'PBS' new 'Sherlock' is brilliant', The Salt Lake Tribune, 23 October 2010.

Podlas, Kimberlianne. 'CSI Effect: Exposing the Media Myth', Fordham Intellectual Property and Media \& Entertainment Law Journal 16, 2006, 429-466.

Rabinow, Paul and Nikolas Rose, 'Biopower Today', BioSocieties, 1, 2006, 195-217. 
Raizendarose. 'My Problem with Molly Hooper', January 2015.

https://www.reddit.com/r/Sherlock/comments/209ybn/my_problem_with_molly_hooper/ (Accessed 28 January 2016.)

Rorke, Robert. 'Detective Peggy Olson', New York Post, March 17, 2013, http://nypost.com/2013/03/17/detective-peggy-olson/. (Accessed 28 January 2016.)

Rose, Nikolas. The Politics of Life Itself: Biomedicine, Power, and Subjectivity in the TwentyFirst Century. Princeton: Princeton University Press, 2007.

Salter, Brian and Mavis Jones, 'Regulating Human Genetics: The Changing Politics of Biotechnology Governance in the European Union, Health, Risk and Society, Vol. 4, No. 3, 2002, 325-340.

Scott-Zechlin, Ariana. 'But It's the Solar System!' Reconciling Science and Faith Through Astronomy' in Louisa Ellen Stein and Kristina Busse (eds.) Sherlock and Transmedia Fandom: Essays on the BBC Series, Jefferson and London: McFarland \& Co, 2012, 56-69.

Shelley, Mary. Frankenstein; or, The Modern Prometheus (London: Penguin, 2007).

Steenberg, Lindsay. Forensic Science in Contemporary American Popular Culture: Gender, Crime, and Science. New York and London: Routledge, 2013.

Steward, Tom. 'Holmes in the Small Screen: The Television Contexts of Sherlock' in Louisa Ellen Stein and Kristina Busse (eds.) Sherlock and Transmedia Fandom: Essays on the BBC Series, Jefferson and London: McFarland \& Co, 2012, 133-147.

Taylor, Rhonda Harris. (2012a) 'A Singular case of Identity: Homesian Shapeshifting' in Lynnette Porter (ed.) Sherlock Holmes for the $21^{\text {st }}$ Century: Essays on New Adaptations, Jefferson and London: McFarland \& Co, 2012, pp. 93-109

Taylor, Rhonda Harris. (2012b) 'The 'Great Game' of Information: The BBC's Digital Native' in Lynnette Porter (ed.) Sherlock Holmes for the $21^{\text {st }}$ Century: Essays on New Adaptations, Jefferson and London: McFarland \& Co, 2012, pp. 128-143.

Thomas, Ronald R. Detective Fiction and The Rise of Forensic Science. Cambridge: Cambridge University Press, 1999.

Toadvine, April. 'The Watson Effect: Civilizing the Sociopath' in Lynnette Porter (ed.) Sherlock Holmes for the $21^{\text {st }}$ Century: Essays on New Adaptations, Jefferson and London: McFarland \& Co, 2012, 48-64.

Williams, Joe. 'It's elementary: Holmes formula shows up in many films and TV shows', McClatchy Tribune, 15 December 2011.

Wollaston, Sam. 'TV review: Sherlock, Alan Titchmarsh's Walks of Fame and Come Dine with Me Down Under', The Guardian, 1 August 2010, http://www.guardian.co.uk/tv-andradio/2010/aug/01/sherlock-alan-titchmarsh-walks (Accessed 28 January 2016). 
This is a pre-print version of an article accepted for publication in New Review of Film and Television Studies (Volume 14, Issue 3, 2016) following peer-review. The definitive publisher authenticated version will be available from: http://www.tandfonline.com/loi/rfts20\#.VzBqBqupp9s

Yap, Stephanie. 'Sherlock in the smartphone age: A new BBC adaptation breathes new life into Arthur Conan Doyle's super sleuth', The Straits Times, 26 May 2011.

Zimonjic, Peter. 'The beautiful and the bland: Glamour is the difference between American and British TV drama', The Ottawa Citizen, 23 September 2006, 1. 